\title{
Export diversity and the relevance of different forms of market experience
}

\author{
Marco Alvarado* \\ Business School, Costa Rica Institute of Technology (ITCR) \\ Business School, 15th Street, 14th Avenue, Cartago, Costa Rica \\ E-mail: malvarado@poliartcr.com \\ Esteban Lafuente \\ Department of Management, Universitat Politècnica de Catalunya \\ (Barcelona Tech) \\ EPSEB, Av. Gregorio Marañón, 44-50, 08028 Barcelona, Spain \\ E-mail: esteban.lafuente@upc.edu \\ Ronald Mora-Esquivel \\ Business School, Costa Rica Institute of Technology (ITCR) \\ Business School, 15th Street, 14th Avenue, Cartago, Costa Rica \\ E-mail: rmora@itcr.ac.cr
}

\section{Citation:}

Alvarado, M., Lafuente, E., \& Mora-Esquivel, R. (2019). Export diversity and the relevance of different forms of market experience. International Journal of Business Environment, 10(3), 209-226. 


\title{
Export diversity and the relevance of different forms of market experience
}

\begin{abstract}
This study evaluates how different forms of human capital-i.e., formal management studies, labor market experience and experience in multinational businesses - explain the export diversity of SMEs, defined as the number of foreign market destinations where the business sells its goods or services. The proposed hypotheses are tested using negative binomial regression models on a unique sample of 117 Costa Rican SMEs for 2017. The findings reveal that labor experience in multinational firms - in particular, experience in managerial positions-is a relevant source of human capital that equip entrepreneurs with specific know-how that is conducive to export diversity, in terms of number of market destinations. Results also show that firm size, age and online sales (e-commerce) are positively correlated to export diversity. Beyond canonical export-related measures, this study offers insights on the importance of including the number of foreign markets (market destinations) in the evaluation of the export performance of SMEs.
\end{abstract}

Keywords: Export diversity, market destinations, human capital, SMEs, Costa Rica.

\section{Introduction}

Internationalization of sales, more concretely exporting, has been invoked as a relevant strategic decision with important implications for small and medium sized enterprises (SMEs) (Aguilera et al., 2017; Autio et al., 2000; Manolova et al., 2010). The successful internationalization of SMEs and the potential benefits of this strategy-e.g., increased competitiveness, market competition, employment growth and technology implementation-have increasingly drawn attention among scholars and policy makers (e.g., Lafuente et al., 2015; Manolova et al., 2010; Vendrell-Herrero et al., 2017).

Although SMEs increasingly engage in high-commitment entry modes (Dimitratos et al., 2010; Prashantham, 2011), exporting remains the most common entry mode chosen by SMEs to go into overseas markets (Morgan et al., 2012). Exporting is especially appealing to SMEs as it represents a lowcommitment entry mode and, therefore, the economic cost and risk borne by the organization are lower compared to alternative foreign entry modes (Leonidou et al., 2010; Manolova et al., 2010). 
Nevertheless, organizations do not materialize the generally positive effects of their international efforts at the same intensity, in terms of export performance outcomes. Businesses face multiple obstacles when developing their exporting strategies, being the uncertainty associated with incomplete information one of the most relevant (Martincus and Carballo, 2008; Patel et al., 2018). In this sense, a number of organizational factors spanning from market experience to the different forms of knowledge embedded in the human capital stock of the business are considered critical elements that help explain the internationalization of SMEs.

The analysis of the relationship between different forms of knowledge and export performance is the focus of this study. More concretely, the objective of this study is to evaluate how different forms of knowledge-i.e., formal education in management, labor market experience and experience in multinational businesses - explain the export performance of SMEs.

Underlying our approach to the relationship between different sources of knowledge and export performance at the business level are two elements that constitute the cornerstones upon which we built the study.

This first critical aspect deals with the definition of export performance. Contrary to most research focused on the analysis of the determinants of export propensity or export intensity (Cassiman and Golovko, 2011; Gomes et al., 2018; Leonidou et al., 2010; Manolova et al., 2002; Sousa, 2004), in this study we focus on a different dimension of export that has received little attention in the literature, namely export diversity. Recent work suggests that successful internationalization is more linked to the capacity of the business to export to a wide array of destinations (Bastos et al., 2018; Boehe and Jiménez, 2018; Brambilla et al., 2012). Canonical measures of export performancei.e., export propensity and intensity-may produce narrow empirical results that can be hard to interpret. Therefore, rather than focusing on the mere act of exporting, we evaluate the determinants of export diversity, that is, the number of foreign markets where the business sells its goods or services (market destinations). By scrutinizing the determinants of export diversity our analysis can explain how different forms of knowledge explain foreign market expansion (Brambilla et al., 2012).

Knowledge is not only heterogeneous between entrepreneurs and businesses, but also in terms of its effects on export diversity. Thus, the second cornerstone of our study relates to the analysis of different forms of knowledge, namely labor market experience and specific experience in international businesses. Most SMEs take advantage of their knowledge-based 
resources to deal with the liabilities of newness and smallness that they face and that condition the implementation of specific strategies, such as internationalization (Das et al., 2007; Lafuente et al., 2015). In this sense, we argue that, besides formal management studies and labor market experience, specific labor experience in multinational businesses may play a decisive role in explaining the export diversity of SMEs. By accumulating experience in multinational businesses, entrepreneurs and managers have access to specific know-how that may help to minimize the ambiguity and uncertainty resulting from incomplete information on foreign market operations (Martincus and Carballo, 2008).

The empirical application uses a unique dataset of 117 Costa Rican SMEs for the year 2017. The Costa Rican setting is attractive for various reasons. First, the successful performance of the Costa Rican economy-e.g., growth in GDP per head at PPP (1991= 7787 US\$, 2016= 14,374 US\$)-and the country's social achievements - in terms of life expectancy (79.6 years) and high level of human capital (adults' tertiary educational attainment in 2016= 40\%) - realized over the last three decades have been acknowledged (OECD, 2016). The positive evolution of Costa Rica's economic and social indicators positions the country atop the Latin American region (together with Chile) (World Economic Forum, 2016), and opened the doors of the OECD, who approved and set out the roadmap for Costa Rica's accession to the Organization on July 8th 2015 (OECD, 2015). Second, the country's economic strategy has favored the diversification of the productive basket reflected in the increased importance of manufacturing activities (manufacturing exports grew from $29.80 \%$ of total exports in 1980 to $57 \%$ in 2015), high-tech electronic products (semi-conductors by Intel) and, more recently, manufacturing goods linked to the medical industry (medical devices and instruments) (Lafuente et al., 2018).

From a research perspective, existing evidence suggests that SMEs operating in emerging markets are increasingly active internationally (Lafuente et al., 2015; Miocevic and Crnjak-Karanovic, 2011; VendrellHerrero et al., 2017); however, most of the literature on Latin American markets focuses on the international behavior of large firms (e.g., Aulakh et al., 2000; Martincus and Carballo, 2008). International business scholars highlight the internationalization of small firms from emerging economies as a fruitful research avenue (Aguilera et al., 2017; Peiris et al., 2012; VendrellHerrero et al., 2017). In particular, our detailed data allows to identify the 
number of foreign markets targeted by the business, as well as the different types of human capital of the entrepreneur.

The remainder of the study is structured as follows. The next section presents the theoretical background and the study hypothesis. In Section 3, the data and the methodology are described. The empirical results are shown in Section 4. Finally, in Section 5 we present the concluding remarks, implications and future research lines.

\section{Background theory and hypotheses development}

\subsection{The resource-based view (RBV) of the firm: A summary of key concepts}

During the last decades, internationalization scholars have started relying on one of the dominant theoretical perspectives in business strategy, namely the resource-based view (RBV) to explain business internationalization (e.g., Evers, 2011; Peng, 2001; Lafuente et al., 2015).

Building on the RBV postulates, businesses are conceived as bundles of resources which they use to develop and maintain a competitive position. These resources are broadly defined as entrepreneurial, organizational and technological (Penrose, 1959). Resources are heterogeneously distributed across businesses and the capacity to create specific combinations conditions the adoption and effectiveness of strategies (Barney, 2001). Bloodgood et al. (1996) relate the above to international expansion arguing that businesses that present unique combinations of resources may have a higher proclivity towards internationalization. Considering that successful internationalization of SMEs relies on mitigating liabilities of smallness and foreignness, the RBV gains relevance and applicability for studying firms' international behavior (Dhanaraj and Beamish, 2003; Loane and Bell, 2006; Ruzzier et al., 2007).

In particular, SMEs from emerging economies are in many cases less resource-endowed compared to their counterparts in more developed markets (Manolova et al., 2010; Martincus and Carballo, 2008) and have to undergo higher internationalization costs. As a natural consequence, SMEs may rely upon inherent, intangible resources that often characterize their technology.

Within the RBV frame, decision-makers-e.g., entrepreneurs or managers - represent some of the most valuable, unique and hard to imitate resources (Evers, 2011; Lafuente et al., 2015). The international business literature acknowledges the decision maker's capital as a valuable asset that 
can enhance SMEs' international activity, often acting as a substitute for tangible resources that tend to be scarce, and hence, constituting a potential source of differential advantage for the internationalized small firm (Leonidou et al., 2010; Manolova et al., 2002).

\subsection{Different forms of human capital and export diversity}

Based on the previous considerations that emphasize entrepreneurs' attributes as relevant for explaining firms' internationalization behavior (Leonidou et al., 2010; Manolova et al., 2002), we selected a set of knowledge-based factors that we expect to influence the export diversity of SMEs. For this reason, we focus on the specific human capital elements of the entrepreneur, including: managerial studies, labor market experience, and specific experience in multinational businesses.

The first analyzed human capital component of the entrepreneur relates to formal education on business management. Formal education represents an investment in human capital and it enhances the entrepreneur's knowledge, problem-solving ability, as well as the capacity to introduce practices within the business that are conducive to superior performance (Unger et al., 2011).

Previous studies show that internationalization is positive associated with formal education (Cavusgil and Naor, 1987; Ibeh, 2004; Lafuente et al., 2015). Furthermore, knowledge resulting from management studies contributes to develop the skills and know-how necessary to run a business and implement different strategies, such as internationalization. In this sense, management studies intensively promoted by universities constitute a valid tool to alleviate potential resources shortages and enhance international business activity, in terms of export diversity. Therefore, we hypothesize that:

H1: Businesses managed by entrepreneurs with management studies will exhibit higher levels of export diversity

The international business literature associates the labor market experience of the entrepreneur with export performance (Evers, 2011; Leonidou et al., 2010). Labor experience equips entrepreneurs and managers with specific knowledge and managerial capabilities that help them to develop more successful international strategies. In addition, Bell et al. (2004) found 
that decision-makers' knowledge and understanding of the industry is significantly associated with high level of international commitment.

Contrary to the case of the formal education that represents an example of codified knowledge, labor market experience is a form of mostly tacit knowledge that is linked to market-oriented observation and action. The accumulation of market experience implies the observation and analysis of a number of aspects relevant for the organization, including, for example, recruiting, implementation of product development strategies, organizational learning, as well as the greater exposure to international competitors in the domestic market (e.g., Lafuente et al., 2018; Leonidou et al., 2010; Manolova et al., 2010). Therefore, we propose that increased labor market experience of managers can act as stimulus for international operations. Thus, the second hypothesis emerges:

H2: Labor market experience accumulated by entrepreneurs is positively associated with export diversity

We now turn our attention to the role of specific labor experience in multinational businesses on export diversity. Existing research emphasizes that international managerial experience is positively correlated with performance metrics related to sales (Monge-González et al., 2011) and internationalization (Ibeh and Wheeler, 2005). Furthermore, Sapienza et al. (2006, p. 923) indicate that if managers can draw from previous international experience they can incorporate the learned routines into the repertoire of emerging routines within the organization; for example, supporting internationalization strategies or international expansion, promoting or developing buyer-supplier relationships, or providing access to business networks. Empirical results show that the international experience of SME's managers positively affects their satisfaction with export profitability and new market entry (Stoian et al., 2011).

Additionally, De Clercq et al. (2008) highlight that foreign direct investment (FDI) may positively impact the export orientation of new ventures by promoting externalities or indirect effects linked to export spillovers. As multinational businesses leading FDIs possess specific assetse.g., management strategy, superior production techniques, know-how, among others - that are difficult to protect in the host country. Many times, these specific tangible or intangible assets are transferred to local businesses via 
commercial collaborations, which will likely improve the knowledge stock of local businesses (Girma et al., 2005; Monge-González et al., 2011). Furthermore, Fosfuri et al. (2001, p. 1) state that labor mobility is among the spillover mechanisms that multinational businesses can create 'when subsidiaries of foreign firms train local employees which will later join local firms or set up their own companies bringing with them all (or part of) the technological, marketing, and managerial knowledge that they have previously acquired'.

From this theory and evidence, we argue that labor market experience in multinational businesses equips entrepreneurs with specific know-how on international operations that are conducive to export diversity. As a result, the following hypothesis emerges:

H3: Businesses managed by entrepreneurs with labor experience in multinational enterprises will exhibit greater export diversity

\section{Data, variable definition and method}

\subsection{Data}

The data used to test the proposed hypotheses comes from a unique dataset of Costa Rican SMEs for the year 2017.

As part of a research project, the questionnaire employed in this work was designed specifically for the purposes of this study by a research team at the Costa Rica Institute of Technology (ITCR). Entrepreneurs are the potential respondents, and they were approached face-to-face with a request to participate in the study. Participants received confirmation on confidentiality and the research team leading the investigation offered feedback on the survey results to the participating businesses in order to encourage entrepreneurs to answer. Data collection was achieved through self-administrated, structured interviews, where the entrepreneur or the manager was asked to answer essentially closed questions. The questionnaire for the survey was applied by a team of the Costa Rica Institute of Technology (ITCR). It should be kept in mind that, following the practice recommended in the literature (Colton and Covert, 2007), the questionnaire was subject to a pre-test in order to correct potentially ambiguous or confusing questions. 
The information was collected between June and August 2017. In a first stage, a total number of 530 owners of SMEs operating in manufacturing, trade and technology-based service sectors in Costa Rica were invited to participate in the study. The final sample comprises information for 82 valid questionnaires, which represents an effective response rate of $15.47 \%$.

Looking at the profile of the sampled firms, note that $82.93 \%$ of SMEs are micro-businesses with up to ten employees, while $17.07 \%$ of SMEs have more than 10 employees. Also, 53.66\% of the surveyed firms are located in the capital region (San Jose).

\subsection{Variable definition}

\subsubsection{Dependent variables}

In this study two dependent variables were used to analyze export behavior, namely export propensity and export diversity. Consistent with the bulk of research on export performance (e.g., Gomes et al., 2018; Cassiman and Golovko, 2011; Leonidou et al., 2010; Lafuente et al., 2015), export propensity is measured via a dummy variable taking the value of one if the business exports, and zero otherwise. The second dependent variable, export diversity, is calculated as the total number of export destinations, that is, the number of foreign markets where the business sells its products or services. Prior research considers this variable as a proxy of internationalization expansion and success (Bastos et al., 2018; Brambilla et al., 2012).

The descriptive statistics presented in Table 1 indicate that $20.51 \%$ of businesses export. Additionally, we note that the export diversity of the sampled businesses is right-skewed: $11.97 \%$ of businesses export to one country, $2.56 \%$ of businesses export to two destinations, $1.71 \%$ of businesses operate in three foreign markets, while the remaining $4.26 \%$ of firms export to more than three international destinations (Table 1).

\section{$<$ INSERT TABLE 1 ABOUT HERE $>$}

\subsubsection{Human capital.}

To operationalize human capital we use different variables. First, labor market experience is measured as the total number of years of market experience of the entrepreneur. Second, we introduce a dummy variable related to the completion of business management studies $(1=$ yes, $0=$ no). Descriptive statistics in Table 2 show that entrepreneurs have, on average, 
8.82 years of labor market experience, while $52.14 \%$ of entrepreneurs have studies on management.

The third human capital variable measures the entrepreneurs' experience in multinational businesses. In this case, entrepreneurs were asked if they had worked, in multinational enterprises (MNEs) before starting their own business (dummy variable: $1=$ yes, $0=$ no). In addition, we split the variable related to experience in multinational businesses in order to distinguish entrepreneurs who worked in middle and top managerial positions (dummy variable: $1=$ yes, $0=$ no) from those whose experience concentrates in operational positions (dummy variable: $1=$ yes, $0=$ no). From Table 2 we observe that $48.72 \%$ of the sampled entrepreneurs have worked in multinational businesses, and that 20.51\% (28.21\%) of entrepreneurs worked middle/top managerial (operational) positions.

\section{<INSERT TABLE 2 ABOUT HERE $>$}

\subsubsection{Control variables.}

We introduce several control variables related to the entrepreneur's profile and the business profile in the different model specifications. More concretely, the control variables related to the entrepreneur include gender (dummy variable taking the value of one for men), and the entrepreneur's age measured in years. The business-related control variables include business age expressed in years, size measured via a set of dummies distinguishing businesses with up to ten employees, between 11 and 20 employees, and more than 20 employees. Note that the average business has 13.49 years of market experience (median age $=8$ years). Also, we introduced a dummy variable that captures if the business offers its products/services online (e-commerce). To account for industry-specific effects, we created a set of dummy variables to identify businesses operating in manufacturing, business services and consumer services sectors. Finally, a set of regional dummy variables were introduced to rule out the effects of different local economic and institutional environments on export diversity. Note that the variables labor experience, entrepreneur's age, and business age were logged to reduce skewness.

\subsection{Method}

In a first stage, we employ a binary choice model to evaluate whether the different types of human capital influence the export propensity of the 
sampled businesses. In this case, the baseline logit model estimated by maximum likelihood has the following form (Greene, 2003):

Export

$$
\begin{aligned}
\text { propensity }_{i} & =\beta_{0}+\beta_{1} \text { Management studies }_{i}+\beta_{2} \text { Labor market experience }_{i}(1) \\
& +\beta_{3} \text { Multinational experience }_{i}+\beta_{4} \text { Control variables }_{i}+\varepsilon_{i}
\end{aligned}
$$

In equation (1) $\beta_{0}$ is the constant term, $\beta_{j}$ is the vector of coefficients estimated for the $j t h$ independent variable, and $\varepsilon_{i}$ is the logistically distributed error term estimated for each individual in the sample (i).

Note that parameters estimated by discrete choice models only indicate the direction of the effect of a focal variable on the dependent variable. For interpretation purposes, the magnitude of the independent variables is determined by the average marginal effect (AME). The AME is the average change in the probability of the response variable as a result of a change in an independent variable across the sampled observations. Through this approach we can estimate marginal effects for each observation, thus the resulting AME not only captures individual-specific characteristics, but also gives more realistic estimation results (Greene, 2005). For each independent variable $(X)$ the AME is estimated as $A M E_{X}=\frac{1}{N} \sum_{i=1}^{N}\left\{F\left(\beta X \mid X_{i}=1\right)-F\left(\beta X \mid X_{i}=0\right)\right\}$.

In the second stage we scrutinize the role of the different sources of human capital on the businesses' export diversity. In this case, the dependent variable is the count number of the number of export market destinations in 2017 (Table 1). Thus, a negative binomial regression is the econometric technique chosen to evaluate export diversity as a function of the independent variables related to the entrepreneur's human capital and the control variables. This approach is the most appropriate when the dependent variable is a count number exhibiting a highly skewed distribution (Greene, 2003 and 2008). In this case, the full model to be estimated has the following form: Export

$$
\begin{aligned}
\text { diversity }_{i} & =\beta_{0}+\beta_{1} \text { Management studies }_{i}+\beta_{2} \text { Labor market experience }_{i} \\
& +\beta_{3} \text { Multinational experience }_{i}+\beta_{4} \text { Control variables }_{i}+\varepsilon_{i}
\end{aligned}
$$


In equation (2) $\beta_{0}$ is the constant term, $\beta_{j}$ is the vector of coefficients estimated for the $j$ th independent variable, and $\varepsilon_{i}$ is the disturbance term estimated for each individual in the sample (i).

In terms of the study hypotheses, we expect that $\beta_{1}>0$ and $\beta_{2}>0$ to confirm that the completion of management studies (H1) and labor experience (H2) are positively correlated with the business' export diversity, respectively. Similarly, a positive result for the coefficient linked to experience in multinational enterprises $\left(\beta_{3}>0\right)$ will corroborate that the experience in multinational enterprises positively influences export diversity (H3).

\section{Results}

This section presents the empirical findings. Table 3 (Section 4.1) shows the results of the logit model evaluating the determinants of export propensity, while Table 4 (Section 4.2) presents the results of the negative binomial regression models that analyze the role of human capital on export diversity. Prior to reporting the results we computed the variance inflation factor (VIF) to test if coefficients are amplified due to correlations across the explanatory variables (collinearity). The average VIF values for the regression models are presented in Tables 3 and 4 . The results for the diagnostic test indicate that for all the independent variables the variance inflation factor is below the commonly used cut-off threshold of ten, confirming that the proposed models do not suffer from collinearity problems (Greene, 2003).

\subsection{Human capital and export propensity}

In this section, we present the findings of the model relating human capital to export propensity.

From the results presented in model 1 of Table 3 we note that the three human capital variables included in the analysis do not have a significant influence on the export propensity of the sampled SMEs. The findings of the complementary analysis in model 2 show that experience in multinational businesses negatively affect export propensity when the entrepreneur accumulated such experience in operational positions. More concretely, the observe that the probability to export falls 17.78 percentage points in 
businesses where the entrepreneur has operational experience in multinational businesses, compared to the probability of entrepreneurs without experience in multinational enterprises (model 2 in Table 3).

\section{$<$ INSERT TABLE 3 ABOUT HERE $>$}

The results of the control variables indicate that export propensity is positively correlated with factors related to scale (business size) and market experience (age) (Table 3). In the case of the firm size variables, the findings in model 2 indicate that the probability to export increases 34.01 percentage points in businesses with more than 20 employees, relative to the probability of micro businesses with less than ten employees.

In the case of variables linked to business age (log age), the result suggests that, if we compare two identical businesses but one reports 13.5 years of market experience and the other is 10\% older (about 15 years of market experience), the probability of exporting of the latter businesses is 1.57 percentage points higher than the probability to export of the younger firm.

\subsection{The role of human capital on export diversity}

This section presents the results of the negative binomial regression models used to test the study hypotheses. In Table 4, model 1 is the specification used to test the study hypotheses relating export diversity to the different forms of human capital. The findings for the complementary analysis are presented in model 2 of Table 4.

The findings for the control variables in Table 4 show that, similar to the case when the dependent variable is export propensity (Table 3 in section 4.1), export diversity is more intense among SMEs with more than 20 employees: firms with more than 20 employees export to three market destinations (3.05) more than micro enterprises with up to ten employees (model 1 in Table 4). Contrary to the results for the export propensity model (section 4.), business age is negatively correlated to export diversity.

Additionally, the findings in Table 4 highlight the importance of online sales for export diversity. By comparing the coefficients in Tables 3 and 4, this result indicates that, among the sampled SMEs, online sales is not important to export; however, offering the business products/services online (e-commerce) has a positive impact on the number of foreign market destinations targeted by the organization. Similar to Vendrell-Herrero (2018), 
this finding highlights the relevance of digital sales for the successful internationalization of businesses, in our case measured as export diversity.

\section{$<$ INSERT TABLE 4 ABOUT HERE $>$}

Concerning the key findings of the study, from model in Table 4 we observe that the completion of management studies is not significantly associated with businesses' export diversity. Therefore, the first hypothesis (H1) that proposes a positive relationship between this form of human capital — management studies—and export diversity is not supported.

In the case of labor market experience, we observe that this coefficient is not statistically significant in relationship with export diversity, thus we fail to support our second hypothesis (H2) that states that the entrepreneur's labor market experience is positively associated with export diversity.

On contrary, the results show a strong positive association between the entrepreneur's experience in multinational enterprises and the export diversity of the business. More concretely, the finding in model 1 of Table 4 indicate that, on average, businesses managed by entrepreneurs with previous experience in multinational enterprises export to 1.59 countries more than those businesses ran by entrepreneurs without such multinational experience. This result is in accordance with our theory that emphasizes the information benefits derived from this type of human capital. Therefore, we confirm our third hypothesis (H3) that businesses managed by entrepreneurs with labor experience in multinational enterprises will exhibit greater export diversity.

The findings in model 2 of Table 4 reveal that the positive impact of experience in multinational enterprises on export diversity exclusively originates from the effect of accumulating experience in managerial positions. The results show that the export diversity of businesses managed by entrepreneurs with managerial experience in multinational enterprises (white collar positions) is significantly higher compared to that of businesses managed by entrepreneurs without previous multinational experience. More concretely, the export diversity of businesses managed by entrepreneurs with multinational experience in while collar positions increases by 2.61 markets, compared to the export diversity level of businesses ran by entrepreneurs without experience in multinational businesses. On contrary, experience in operational positions (blue collar positions) has a negative effect on export diversity. In this case, the export diversity of businesses managed by entrepreneurs with previous multinational experience in blue collar positions 
falls by 1.10 countries, relative to the average export diversity of businesses managed by entrepreneurs without experience in multinational enterprises.

\section{Concluding remarks, implications, and future research lines}

\subsection{Theoretical contribution}

The study presented in this paper has produced novel empirical evidence on the relationship between different forms of human capital and an export performance variable that has received little attention in prior research, namely export diversity. We hypothesized that the benefits of multinational enterprises go beyond the mere creation of jobs, and that individuals can accumulate valuable know-how by working in this type of organization. We argue that this multinational experience is transferred to the entrepreneur who can exploit this specific knowledge in his/her subsequent venture.

From an academic perspective, our results fuel the debate on the need to analyze businesses' export behavior using metrics that go beyond canonical variables related to export propensity that may offer incomplete and hard to interpret results (e.g., Bernard and Jensen, 1999; Lafuente et al., 2015).

Additionally, our findings corroborate that labor experience generated in multinational enterprises does not explain export propensity; however, this type of human capital significantly explains SMEs' strategic choices related to the number of foreign markets targeted by organizations. This result highlights the relevance of distinguishing the specific impacts of different types of human capital, in particular the accumulated experience originated from working in multinational enterprises.

Finally, by proposing a managerial analysis of export diversity in a developing economy-i.e., Costa Rica - this study contributes to increase the emerging body of research dealing with both the internationalization of Latin American firms (Aguilera et al., 2017; Vendrell-Herrero, 2017), and the determinants and effects of businesses' export diversity in developed and developing economies (e.g., Bastos et al., 2018; Brambilla et al., 2012).

\subsection{Policy implications}

The results of this paper have relevant policy implications. Export support policies tend to sponsor the internationalization of relatively large and 
experienced SMEs managed by experienced entrepreneurs on the basis that these capacities are necessary for a successful internationalization (Martincus and Carballo, 2008). Nevertheless, little attention has been paid to the potentially beneficial effect of experience in multinational businesses. In this sense, policy interventions aimed at fostering the internationalization of SMEs should not exclusively focus on businesses that fit the traditional exporter profile. Successful export policies are conditional on the targeted group of beneficiaries, and we argue that internationalization support policies should also target organizations managed by individuals with previous experience in multinational enterprises, in particular in managerial positions.

Additionally, we propose that policy makers should employ a greater number of criteria when it comes to evaluate the internationalization of SMEs at the territorial level. Canonical metrics based on export propensity are unquestionably useful but may generate incomplete data about the quality of the international activity of local SMEs. In this case, a more effective monitoring of the international activities of SMEs may contribute to the design of highly inter-related, heterogeneous policies oriented to the promotion of exports among SMEs without international activity, and to enhance the participation of SMEs in international markets by increasing both export intensity as well as the number of foreign market destinations.

In the specific case of Costa Rica, this aspect is of great relevance for the top export promotion agency of the country (Procomer: www.procomer.com). This agency supports the internationalization (exports) of local firms by offering specific training programs and helping businesses with countryspecific export bureaucracy. In this sense, we suggest that policy makers need to turn their attention to the design of tailor-made training programs that equip specific groups of exporters (e.g., new and experienced exporters, or according to the businesses' economic activity) with the specific knowledge and tools necessary to optimize their export-led efforts.

\subsection{Limitations and further research lines}

A number of limitations to the present research must, however, be mentioned. These limitations, in turn, represent avenues for future research.

First, and similar to other studies on export behavior (e.g., Brambilla et al., 2012; Gomes et al., 2018; Lafuente et al., 2015), our study does not permit to directly analyze the effect of different types of human capital on the business' specific market choices. We present various interpretations of how 
experience in multinational enterprises enhances the entrepreneur's human capital by providing relevant export-related know-how; however, we do not evaluate how this relationship conditions the choice of export markets (Berbel-Pineda et al., 2012), nor do we evaluate how business performance is affected by differences in the selected market destinations (e.g., developed viz.-a-viz. developing markets) (Bastos et al., 2018). Specifically designed future research on this issue would be valuable. For example, future research on the businesses' export diversity should include in the analysis the geographic diversity of the foreign markets targeted by organizations (Boehe and Jiménez, 2018).

In a closely related manner, a second area of future research should evaluate how different types of knowledge-whether resulting from knowledge exploitation or experiential learning - acquired by the entrepreneur working in multinationals or locals businesses affect export behavior (propensity, intensity of diversity) and other performance metrics (Cooper, 1985; Feeser and Willard, 1990). Third, future studies should focus on the analysis of the effects of business' strategic choices on the development of international-related capabilities and, consequently, export behavior (propensity, intensity and diversity). For example, future studies should evaluate the joint effect of export diversity and organizational factors-e.g., organizational culture - on productivity or alternative performance metrics (Sáenz-Castro et al., 2016). Additionally, and in light of the increased relevance of product-service innovations for business performance (Bustinza et al., 2018), future research should evaluate whether the export diversity of knowledge-intensive business service (KIBS) firms is affected by the international possibilities of servitization processes, and whether this effect is different compared to that of businesses operating in other industries.

Finally, the geographical specificity of the study as well as the crosssectional nature of the dataset used in this work calls for obvious caution when interpreting and generalizing our findings.

\section{References}

Aaby, N.E. \& Slater, S., 1989. Management influences on export performance: a review of the empirical literature 1978-1988. International Marketing Review, 6(4), pp. 7-25. 
Aguilera, R.V., Ciravegna, L., Cuervo-Cazurra, A., \& Gonzalez-Perez, M.A., 2017. Multilatinas and the internationalization of Latin American firms. Journal of World Business, 52(4), pp. 447-460.

Aulakh, P.S., Kotabe, M., \& Teegen, H., 2000. Export Strategies and Performance of Firms from Emerging Economies: Evidence from Brazil, Chile, and Mexico. Academy of Management Journal, 43, pp. 342-361.

Autio, E., Sapienza, H.J., \& Almeida, J.G., 2000. Effects of age at entry, knowledge intensity, and imitability on international growth. Academy of Management Journal, 43(5), pp. 909-924.

Barney, J., 2001. Resource-based theories of competitive advantage: a ten year retrospective of the resource-based view. Journal of Management, 27 (6), pp. 643-650.

Beleska-Spasov, E., 2014. Determinants and measures of export performance: Comprehensive literature review. Journal of Contemporary Economic and Business Issues, 1(1), pp. 63-74.

Bell, J., Callaghan, I., Demick, D., \& Scharf, F., 2004. Internationalisation entrepreneurship education. Journal of International Entrepreneurship, 2 (1-2), pp. 109-124.

Berbel-Pineda, J.M., Ramón-Jerónimo, M.J., \& Vásquez-Carrasco, R., 2012. La selección de mercados preferentes como clave en la internacionalización empresarial. Tec Empresarial, 6(1), pp. 21-33.

Bernard, A. \& Jensen, J.B., 1999. Exceptional exporter performance: cause, effect, or both? Journal of International Economics, 47, pp. 1-25.

Bilkey, W., 1978. An attempted integration of the literature on the export behavior of firms. Journal of International Business Studies, 9(1), pp. 3346.

Bloodgood, J., Sapienza, H.J., \& Almeida, J.G., 1996. The internationalisation of new high-potential US ventures: antecedents and outcomes. Entrepreneurship Theory and Practice, 20 (4), pp. 61-76.

Boehe, D. \& Jiménez, A., 2018. Does the sequencing of related and unrelated export diversification matter? Evidence from Colombian exporters. International Business Review, in press. doi: 10.1016/j.ibusrev.2018.04.005 
Brambilla, I., Lederman, D., \& Porto, G., 2012. Exports, export destinations, and skills. American Economic Review, 102(7), pp. 3406-3438.

Bustinza, O.F., Vendrell-Herrero, F., Gomes, E., Lafuente, E, Opazo-Basáez, M., Rabetino, R., \& Vaillant, Y., 2018. Product-service innovation and performance: unveiling the complexities. International Journal of Business Environment, 10(2), pp. 1-10.

Cassiman, B. \& Golovko, E., 2011. Innovation and internationalization through exports. Journal of International Business Studies, 42, pp. 56-75.

Cavusgil, S.T. \& Naor, J., 1987. Firm and management characteristics as discriminators of export marketing activity. Journal of Business Research, 15 (3), pp. 221-235.

Cooper, A.C., 1985. The role of incubator organizations in the founding of growth-oriented firms. Journal of Business Venturing, 1(1), 317-326.

Das, S., Roberts, M.J., \& Tybout, J.R., 2007. Market entry costs, producer heterogeneity, and export dynamics. Econometrica, 75, pp. 837-873.

De Clercq, D., Hessels, J., \& Van Stel, A., 2008. Knowledge spillovers and new ventures' export orientation. Small Business Economics, 31(3), pp. 283-303.

Dhanaraj, C. \& Beamish, P.W., 2003. A resource-based approach to the study of export performance. Journal of Small Business Management, 41 (3), pp. 242-261.

Eaton, J., Kortum, S., \& Kramarz, F., 2004. Dissecting trade: Firms, industries, and export destinations. American Economic Review, 94(2), pp. 150-154.

Evers, N., 2011. International new ventures in 'low tech' sectors: a dynamic capabilities perspective. Journal of Small Business and Enterprise Development, 18 (3), pp. 502-528.

Feeser, H.R. \& Willard, G.E., 1990. Founding strategy and performance: A comparison of high and low growth high tech firms. Strategic Management Journal, 11(2), 87-98. 
Fosfuri, A., Motta, M., \& Rønde, T., 2001. Foreign direct investment and spillovers through workers' mobility. Journal of International Economics, 53(1), pp. 205-222.

Girma, S., Kneller, R., \& Pisu, M., 2005. Exports versus FDI: an empirical test. Review of World Economics, 141(2), pp. 193-218.

Gomes, E., Vendrell-Herrero, F., Mellahi, K., Angwin, D., \& Sousa, C., 2018. Testing the self-selection theory in high corruption environments: Evidence from African SMEs. International Marketing Review, in press. doi: 10.1108/IMR-03-2017-0054

Greene, W., 2003. Econometric Analysis (5th Ed.). Upper Saddle River, New Jersey: Prentice-Hall.

Greene, W., 2008. Functional forms for the negative binomial model for count data. Economics Letters, 99, pp. 585-590.

Ibeh, K.I.N., 2004. Furthering export participation in less performing developing countries: the effects of entrepreneurial orientation and managerial capacity factors. International Journal of Social Economics, 31 (1/2), pp. 94-110.

Ibeh, K.I.N. \& Wheeler, C.N., 2005. A resource-centred interpretation of export performance. International Entrepreneurship and Management Journal, 1 (4), pp. 539-556.

Katsikeas, C.S., Leonidou, L.C., \& Morgan, N.A., 2000. Firm-level export performance assessment: review, evaluation, and development. Journal of the Academy of Marketing Science, 28(4), pp. 493-511.

Kneller, R. \& Pisu, M., 2005. Industrial linkages and export spillovers from FDI. Research paper series: Globalisation, Productivity and Technology. Centre for Research on Globalisation and Economic Policy. University of Nottingham, pp. 1-38. $\quad$ Retrieved from https://www.nottingham.ac.uk/gep/documents/papers/2005/05-20.pdf $(02 / 15 / 2018)$.

Lafuente, E., Stoian, C., \& Rialp, J., 2015. From Export Entry to Deinternationalisation through Entrepreneurial Attributes. Journal of Small Business and Enterprise Development, 22(1), pp. 21-37. 
Lafuente, E., Vaillant, Y., \& Leiva, J.C., 2018. Sustainable and Traditional Product Innovation without Scale and Experience, but only for KIBS! Sustainability, 10(4), 1169.

Leonidou, L., Katsikeas, C., \& Coudounaris, D., 2010. Five decades of business research into exporting: A bibliographic analysis. Journal of International Management, 16(1), pp. 78-91.

Loane, S. \& Bell, J., 2006. Rapid internationalisation among entrepreneurial firms in Australia, Canada, Ireland and New Zealand: an extension of the network approach. International Marketing Review, 23 (5), pp. 467-485.

Manolova, T.S., Brush, C.G., Edelman, L.F., \& Greene, P.G., 2002. Internationalisation of small firms. Personal factors revisited. International Small Business Journal, 20 (1), pp. 9-31.

Manolova, T.S., Manev, I.M., \& Gyoshev, B.S., 2010. In good company: the role of personal and inter-firm networks for new-venture internationalisation in a transition economy. Journal of World Business, 45 (3), pp. 257-265.

Martincus, C.V. \& Carballo, J., 2008. Is export promotion effective in developing countries? Firm-level evidence on the intensive and the extensive margins of exports. Journal of International Economics, 76(1), pp. 89-106.

Miocevic, D., \& Crnjak-Karanovic, B., 2011. Cognitive and InformationBased Capabilities in the Internationalisation of Small and Medium-Sized Enterprises: The Case of Croatian Exporters. Journal of Small Business Management, 49 (4), pp. 537-557.

Monge-González, R., Leiva, J.C., \& Alegre, J., 2011. Creación de Empresas por parte de Ex Empleados de Empresas Multinacionales de Alta Tecnología en Costa Rica. Tec Empresarial, 5(3), pp. 9-20.

Morgan, N.A., Katskieas, C.S., \& Vrohies, D.W., 2012. Export marketing strategy implementation, export marketing capabilities, and export venture performance. Journal of the Academy of Marketing Science, 40 (2), pp. 271-289.

OECD, 2015. OECD Establishes Roadmap for Membership with Costa Rica. OECD Newsroom, 15 July 2015. Available online: 
http://www.oecd.org/newsroom/oecd-establishes-roadmap-formembership-with-costa-rica.htm (last retrieved on 28 May 2018).

OECD, 2016. OECD Economic Surveys: Costa Rica 2016-Economic Assessment. OECD Publishing: Paris, France.

Patel, P.C., Criaco, G., \& Naldi, L., 2018. Geographic diversification and the survival of born-globals. Journal of Management, 44(5), pp. 2008-2036.

Peiris, I.K., Akoorie, M.E., \& Sinha P., 2012. International entrepreneurship: a critical analysis of studies in the past two decades and future directions for research. Journal of International Entrepreneurship, 10, pp. 279-234.

Peng, M.W., 2001. The resource-based view and international business. Journal of Management, 27 (6), pp. 803-829.

Penrose, E., 1959. The Theory of the Growth of the Firm. John Wiley: New York, NY.

Prashantham, S., 2011. Social capital and Indian micromultinationals. British Journal of Management, 22(1), pp. 4-20.

Rocha, R.S., 2017. Racing to the bottom, or climbing to the top? Local responses to the internationalisation of trade in the Brazilian textile and garments industry. International Journal of Business Environment, 9(3), pp. 225-246.

Ruzzier, M., Antoncic, B., Hisrich, R.D., \& Konecnik, M., 2007. Human capital and SME internationalisation: a structural equation modelling study. Canadian Journal of Administrative Science, 24 (1), pp. 15-29.

Sáenz-Castro, D., Chang, E. \& Martínez, J., 2016. El impacto de la cultura organizacional sobre la estrategia competitiva y su influencia en el desempeño exportador de las pymes de barranquilla, Colombia. Tec Empresarial, 10(2), pp. 7-16.

Sapienza, H.J., Autio, E., George, G., \& Zahra, S.A., 2006. A capabilities perspective on the effects of early internationalization on firm survival and growth. Academy of Management Review, 31(4), pp. 914-933.

Sousa, C., 2004. Export performance measurement: an evaluation of the empirical research in the literature. Academy of Marketing Science Review, 9, pp. 1-22. 
Stoian, M.C., Rialp, A., \& Rialp, J., 2011. Export performance under the microscope: A glance through Spanish lenses. International Business Review, 20(2), pp. 117-135.

Unger, J., Rauch, A., Frese, M., Rosenbusch, N., 2011. Human capital and entrepreneurial success: A meta-analytical review. Journal of Business Venturing, 26(3), pp. 341-358.

Vendrell-Herrero, F., Gomes, E., Collinson, S., Parry, G., \& Bustinza, O.F., 2018. Selling digital services abroad: How do extrinsic attributes influence foreign consumers' purchase intentions? International Business Review, 27(1), pp. 173-185.

Vendrell-Herrero, F., Gomes, E., Mellahi, K., \& Child, J., 2017. Building international business bridges in geographically isolated areas: The role of foreign market focus and outward looking competences in Latin American SMEs. Journal of World Business, 52(4), pp. 489-502.

Welch, L.S., \& Luostarinen, R., 1988. Internationalization: Evolution of a concept. Journal of General Management, 14(2), pp. 34-55.

White, S., Griffith, D.A., \& Ryans, J.K. Jr., 1998. Measuring export performance in service industries. International Marketing Review, 15(3), pp. 188-204.

Wolff, J.A. \& Pett, T.L., 2000. Internationalization of small firms: An examination of export competitive patterns, firm size, and export performance. Journal of Small Business Management, 38(2), pp. 34-47.

World Economic Forum, 2016. The Global Competitiveness Report 20162017. World Economic Forum: Geneva, Switzerland.

Yamakawa, Y., Peng, M.W., \& Deeds, D.L., 2008. What drives new ventures to internationalise from emerging to developed economies? Entrepreneurship Theory and Practice, 32 (1), pp. 59-82. 


\section{List of Tables}

Table 1. Export propensity and export diversity among the sampled businesses

\begin{tabular}{|l|c|}
\hline & Average \\
\hline Panel A: Export propensity & $0.2051(0.4055)$ \\
\hline Panel B: Export diversity & 1.7500 (2.2889) \\
\hline $\begin{array}{l}\text { Number of foreign market destinations among } \\
\text { exporting businesses }\end{array}$ & 0.1197 \\
\hline \% of businesses exporting to 1 destination: & 0.0256 \\
\hline \% of businesses exporting to 2 destinations: & 0.0171 \\
\hline \% of businesses exporting to 3 destinations: & 0.0256 \\
\hline \% of businesses exporting to 4 destinations: & 0.0085 \\
\hline \% of businesses exporting to 7 destinations: & 0.0085 \\
\hline \% of businesses exporting to 8 destinations: & \\
\hline
\end{tabular}

Note: sample size $=117$ businesses. 
Table 2. Descriptive statistics for the selected variables

\begin{tabular}{|c|c|c|}
\hline & Average & $\begin{array}{l}\text { Standard } \\
\text { deviation }\end{array}$ \\
\hline \multicolumn{3}{|l|}{ Export performance: } \\
\hline Export propensity & 0.2051 & 0.4055 \\
\hline $\begin{array}{l}\text { Export diversity: number of export } \\
\text { destinations for exporting businesses }\end{array}$ & 1.7500 & 2.2889 \\
\hline \multicolumn{3}{|l|}{ Human capital variables: } \\
\hline Labor experience (years) & 8.82 & 8.31 \\
\hline Management studies (dummy) & 0.5214 & 0.5017 \\
\hline $\begin{array}{l}\text { Experience in multinational firms (dummy): } \\
\text { Total }\end{array}$ & 0.4872 & 0.5020 \\
\hline $\begin{array}{l}\text { Experience in multinational firms (dummy): } \\
\text { Top management }\end{array}$ & 0.2051 & 0.4055 \\
\hline $\begin{array}{l}\text { Experience in multinational firms (dummy): } \\
\text { Operations }\end{array}$ & 0.2821 & 0.4519 \\
\hline \multicolumn{3}{|l|}{ Entrepreneurs' control variables: } \\
\hline Gender (1 for men) & 0.5556 & 0.4990 \\
\hline Entrepreneur's age (ln years) & 42.38 & 10.59 \\
\hline \multicolumn{3}{|l|}{ Business control variables: } \\
\hline Business size: up to 10 employees & 0.8205 & 0.3854 \\
\hline Business size: $11-20$ employees & 0.0769 & 0.2676 \\
\hline Business size: more than 20 employees & 0.1026 & 0.3047 \\
\hline Business age (years) & 13.49 & 15.51 \\
\hline Online sales (e-commerce dummy variable) & 0.2051 & 0.4055 \\
\hline Manufacturing businesses & 0.0940 & 0.2931 \\
\hline Business services sectors & 0.3333 & 0.4734 \\
\hline Consumer services sectors & 0.2564 & 0.4385 \\
\hline Retail industry & 0.2991 & 0.4599 \\
\hline Location: San Jose & 0.4957 & 0.5021 \\
\hline Location: Alajuela & 0.1538 & 0.3624 \\
\hline Location: Cartago & 0.1624 & 0.3704 \\
\hline Location: Guanacaste & 0.0171 & 0.1302 \\
\hline Location: Heredia & 0.1453 & 0.3539 \\
\hline Location: Puntarenas & 0.0256 & 0.1587 \\
\hline
\end{tabular}

Note: sample size $=117$ businesses. 
Table 3. Logit regression results: Determinants of export propensity

\begin{tabular}{|c|c|c|c|c|}
\hline & \multicolumn{2}{|c|}{ Model 1} & \multicolumn{2}{|c|}{ Model 2} \\
\hline & Coefficient & AME & Coefficient & AME \\
\hline Labor experience (ln years) & $-0.4856(0.4866)$ & $-0.0568(0.0557)$ & $-0.6532(0.5643)$ & $-0.0731(0.0618)$ \\
\hline Experience in multinational firms: Total & $-0.5033(0.6093)$ & $-0.0589(0.0700)$ & & \\
\hline $\begin{array}{l}\text { Experience in multinational firms: Top } \\
\text { management }\end{array}$ & & & $0.4166(0.8148)$ & $0.0466(0.0914)$ \\
\hline $\begin{array}{l}\text { Experience in multinational firms: } \\
\text { Operations }\end{array}$ & & & $-1.5892(0.7236)^{* *}$ & $-0.1778(0.0835)^{* *}$ \\
\hline Management studies & $-0.3465(0.6922)$ & $-0.0405(0.0804)$ & $-0.2882(0.6827)$ & $-0.0322(0.0758)$ \\
\hline Online sales (e-commerce) & $0.2487(0.6273)$ & $0.0291(0.0723)$ & $0.3049(0.6373)$ & $0.0341(0.0702)$ \\
\hline Gender (1 for men) & $1.1963(0.7542)$ & $0.1399(0.0876)$ & $1.3432(0.8201)^{*}$ & $0.1502(0.0888)^{*}$ \\
\hline Entrepreneur’s age (ln years) & $-1.0792(1.4472)$ & $-0.1262(0.1698)$ & $-1.9589(1.8105)$ & $-0.2191(0.2004)$ \\
\hline Business size: 11-20 employees & $0.4945(1.0198)$ & $0.0615(0.1379)$ & $0.3072(0.9518)$ & $0.0345(0.1121)$ \\
\hline Business size: more than 20 employees & $2.2815(0.8142)^{* * *}$ & $0.3701(0.1380)^{* * *}$ & $2.3116(0.9137) * *$ & $0.3401(0.1372)^{* *}$ \\
\hline Business age (ln years) & $1.1176(0.3596)^{* * *}$ & $0.1307(0.0372)^{* * *}$ & $1.4024(0.3550)^{* * *}$ & $0.1569(0.0341)^{* * *}$ \\
\hline Industry dummies & Yes & & Yes & \\
\hline Geographic dummies & Yes & & Yes & \\
\hline Intercept & $-0.2374(2.2737)$ & & 2.5139 (5.4014) & \\
\hline Log likelihood & -44.0230 & & -41.6295 & \\
\hline Wald test (Chi2) & $28.85 * * *$ & & $28.88 * * *$ & \\
\hline Pseudo R2 & 0.2585 & & 0.2988 & \\
\hline Average VIF (min-max) & $1.27(1.09-1.85)$ & & $1.31(1.10-1.85)$ & \\
\hline Observations & 117 & & 117 & \\
\hline
\end{tabular}

Note: AME refers to the average marginal effects. Micro-business (up to ten employees) is the omitted size category. The omitted sector category is consumer services, while Sale Jose (capital) is the omitted geographic dummy variable. Robust standard errors adjusted by heteroskedasticity are presented in brackets. *, **, *** indicate significance at the $10 \%, 5 \%$, and $1 \%$, respectively. 
Table 4. Negative binomial regression results: Determinants of export diversity (number of market destinations)

\begin{tabular}{|l|c|c|}
\hline & Model 1 & Model 2 \\
\hline Labor experience (ln years) & $0.5977(0.5223)$ & $0.7991(0.5413)$ \\
\hline $\begin{array}{l}\text { Experience in international } \\
\text { businesses: Total }\end{array}$ & $1.5929(0.7446)^{* *}$ & \\
\hline $\begin{array}{l}\text { Experience in international } \\
\text { businesses: Top management }\end{array}$ & & $2.6103(0.7991)^{* * *}$ \\
\hline $\begin{array}{l}\text { Experience in international } \\
\text { businesses: Operations }\end{array}$ & & $-1.1055(0.6473)^{*}$ \\
\hline Management studies & $1.2082(0.8276)$ & $0.8497(0.6513)$ \\
\hline Online sales (e-commerce) & $1.5139(0.8304)^{*}$ & $1.3076(0.6504)^{* *}$ \\
\hline Gender (1 for men) & $0.4250(0.5995)$ & $0.7710(0.6166)$ \\
\hline Entrepreneur's age (ln years) & $-2.5896(1.4137)^{*}$ & $-4.1976(2.1024)^{* *}$ \\
\hline Business size: 11-20 employees & $-2.0591(1.2444)^{*}$ & $-1.7180(0.9059)^{*}$ \\
\hline $\begin{array}{l}\text { Business size: more than 20 } \\
\text { employees }\end{array}$ & $1.8600(0.7846)^{* *}$ & $3.0497(0.9543)^{* * *}$ \\
\hline Business age (ln years) & $1.5205(0.5118)^{* * *}$ & $1.1667(0.3173)^{* * *}$ \\
\hline Industry dummies & Yes & Yes \\
\hline Geographic dummies & Yes & Yes \\
\hline Intercept & $1.1989(5.2890)$ & $7.2428(7.4650)$ \\
\hline Log likelihood & -59.7830 & -55.3518 \\
\hline Wald test (Chi2) & $26.60 * * *$ & $37.40^{* * *}$ \\
\hline Pseudo R2 & 0.0774 & 0.1451 \\
\hline Average VIF (min-max) & $1.27(1.09-1.85)$ & $1.31(1.10-1.85)$ \\
\hline Observations & 117 & 117 \\
\hline
\end{tabular}

Robust standard errors adjusted by heteroskedasticity are presented in brackets. Microbusiness (up to ten employees) is the omitted size category. The omitted sector category is consumer services, while San José (capital) is the omitted geographic dummy variable. *, **, *** indicate significance at the $10 \%, 5 \%$, and $1 \%$, respectively. 